\title{
Modeling distribution of Schinus molle L. in the Brazilian Pampa: insights on vegetation dynamics and conservation of the biome
}

\author{
R.P.M. Lemos, C.B. D’Oliveira, C.R. Rodrigues, L.F.W. Roesch, V.M. Stefenon
}

Lemos R.P.M., D'Oliveira C.B., Rodrigues C.R., Roesch L.F.W., Stefenon V.M., 2014. Modeling distribution of Schinus molle L. in the Brazilian Pampa: insights on vegetation dynamics and conservation of the biome. Ann. For. Res. 57(2): 205$214,2014$.

Abstract. Natural establishment of forests in the Brazilian Pampa biome should occur due to soil, hydrology and climate conditions, although no significant forest expansion over grassland has been noticed, precluded mainly by human interference and lack of environmental management. In this study, we used niche-modeling distribution of the tree species Schinus molle L. based on climatic variables to access the vegetation dynamics of the Brazilian Pampa and to develop strategies that assure the conservation of this biome, concerning both grassland and forest formations. Here we show that a large area of the Brazilian Pampa is suitable for expansion of $S$. molle populations, supporting the forest expansion over grassland as a natural process in this biome. We propose that the current absence of tree species expansion over the grassland in these areas is a result of the resilience of the grassland and of human interferences through expansion of agriculture, ranching and forestry with exotic species. Therefore, conservationist actions should focus on establishing preservation unities that include forest populations and grassland, while environmental management should be applied just in farming areas with historical human interference. Such actions will respect the ecological dynamics of the Pampa and value the forest formations in this grassland-dominated environment. Keywords forest expansion, Peruvian pepper tree, maximum entropy, vegetation dynamic.

Authors. Rafael P.M. Lemos, Cristiane B. D’Oliveira, Carla R. Rodrigues, Luiz F.W. Roesch, Valdir M. Stefenon (valdirstefenon@unipampa.edu.br) - Universidade Federal do Pampa, Campus São Gabriel, Av. Antonio Trilha, 1847, 97300-000, São Gabriel, RS, Brazil.

Manuscript received July 17, 2014; revised November 06, 2014; accepted November 14, 2014; online first November 27, 2014. 


\section{Introduction}

Schinus molle L. (Anacardiaceae), widely known as Peruvian pepper tree, is an evergreen dioecious tree species (Figure 1A) with natural occurrence in the Pampa Biome (Sobral \& Jarenkow 2006). As a pioneer species, S. molle is very important for the ecological succession, creating environmental conditions for forest establishment, as well as nesting sites and source of food for birds and mammals. It can flower at any time of the year, and female trees bear a mixture of ripe and unripe fruits (Figure 1B) most of the time, making their seeds available for dispersal throughout the year (Milton et al. 2007). Seeds are dispersed by birds, mammals and in running water, while seedlings become established in washes, ravines, old fields and rock outcrops (Howard \& Minnich 1989). Schinus molle is recognized by its use in folk's medicine (Dikshit et al. 1986), by the pharmaceutical uses of its essential oils (Marongiu et al. 2004) and by the spicy pink pepper (Goldstein \& Coleman 2004).

Currently, populations of $S$. molle are found in the Brazilian Pampa as scattered formations, growing mainly in disturbed environments as well as in primary forest formations. Since no historical registers about the distribution of $S$. molle in the Brazilian Pampa are available, the reconstruction of the species dynamics is not an easy task. Schinus molle is recognized as an invasive species in South Africa (Iponga et al. 2009), Hawaii (Asner et al. 2008) and California (Howard \& Minnich 1989), with a higher dispersion capacity and large ability to establish in new environments. These two characteristics offer good opportunities for gaining insights regarding the ecological dynamics of tree species populations in the Brazilian Pampa and understanding the needs for the conservation of this biome. As a pioneer species, $S$. molle may generate suitable environments within the Pampa biome for the establishment of secondary tree species such as Luehea divaricata, Cordia trichotoma, Eugenia uniflora and Myrsine laetevirens.

The Brazilian Pampa is restricted to the southernmost region of the country, where it occupies about $176,496 \mathrm{~km}^{2}$ comprising a mosaic of different vegetation physiognomies, dominated by grassland environments (Roe-

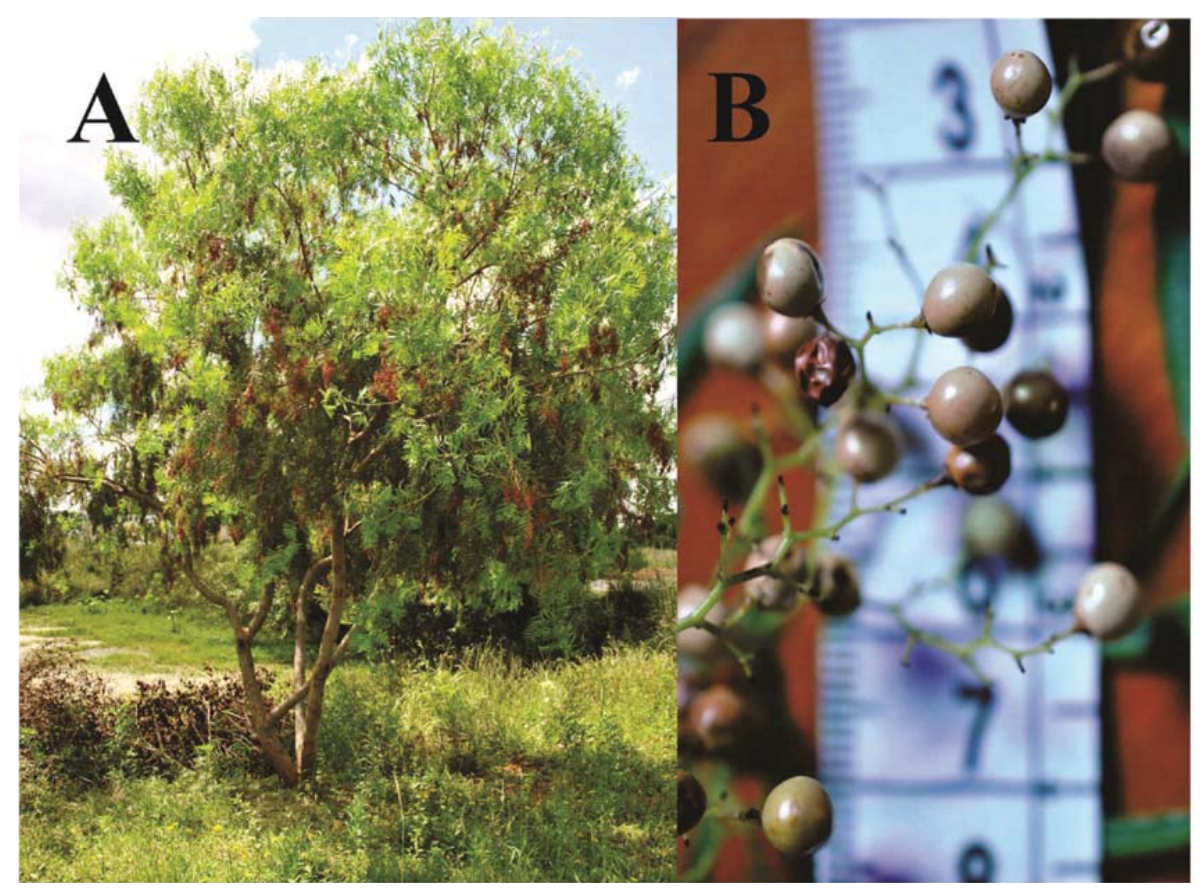

Figure 1 Schinus molle in the Pampa stricto sensu. (A) Female individual of S. molle in its natural habitat. (B) Ripe fruits of S. molle 
sch et al. 2009). The current climatic conditions and the depth of the soils in the Brazilian Pampa have been considered favorable for the development of forests, although no extensive expansion of tree populations is observed in this biome (Bredekamp et al. 2002, Pillar 2003, Roesch et al. 2009). Consequently, the question remains: which features are determinants in precluding the expansion of the tree populations over the grassland in the Pampa Biome? Although it is an old question (e.g. Rambo 1956, Hueck 1966, Klein 1975), no studies have tried to answer it through empirical research of ecological dynamics of tree species. Historically, forest cover in the Brazilian Pampa remains restricted to formations along river margins and nucleations within the grassland formations, mainly as result of the grassland resilience and of human interference through expansion of agriculture, ranching and monoculture forestry with exotic species, mainly with Eucalyptus spp.

Although forests are not the most significant plant component of the Pampa biome (more than 3,000 grass species against about 200 tree species: Roesch et al. 2009, OliveiraFilho et al. 2013), woody formations are quite important in this region. Forest formations are crucial for the protection of watercourses, as housing and nesting area for several birds, mammals and epiphyte plants, holding high biodiversity (Roesch et al. 2009). Although exotic tree species may also contribute to these environmental services, native species are expected to perform better as effect of the coevolution with their biotic environment, including host-pathogen interactions. Thus, conserving regional biodiversity is directly associated to the species occurring in a region and the several biotic and abiotic features that comprise an ecosystem (Myers et al. 2000).

Aiming to have rapid information towards taking decisions about nature preservation, conservationists have increasingly relied on predictive models to provide decision-makers with information on species distribution. In addition, modeling species distribution across ecosystems has become a strategic tool in documenting biodiversity on the planet and is crucial to understanding the effect of multiple stresses caused by climate and human-induced changes (Saatchi et al. 2008).

Since forest expansion has been neglected in the discussions about conservation of the Brazilian Pampa, the present study aimed to highlight natural dynamics of tree populations in the Pampa biome concerning ecological succession of the vegetation, by determining likely occurrence areas of the pioneer species $S$. molle in the Pampa biome in Southern Brazil, using maximum entropy and GIS-based modeling. Schinus molle is a native tree species of the Pampa biome, with high dispersion capacity and high adaptability. These characteristics may help the establishment of primary forest formations in areas where the abiotic conditions are suitable, creating environmental conditions for the establishment of species of later successional stages and forest expansion. These characteristics make $S$. molle a useful species to study the dynamics of tree populations in the Pampa biome.

In this study we intend to answer two main questions: (1) is the expansion of tree species over grassland an expected process in the Brazilian Pampa? (2) Which strategies should be used to guarantee the natural dynamic and conservation of this biome?

\section{Material and methods}

\section{Field survey and data collection}

Data about the occurrence of $S$. molle populations were collected in the savanna, steppicsavanna and steppe portions of the Brazilian Pampa, hereafter called Pampa sensu stricto $\left(29^{\circ} 00^{\prime}-32^{\circ} 00^{\prime} \mathrm{S}, 53^{0} 30^{\prime}-58^{\circ} 00^{\prime} \mathrm{W}\right)$. The Pampa sensu stricto (Figure 2A) is characterized by large extensions of grassy vegetation with occurrence of tree species as gallery for- 
ests and scattered forest formations across the grasslands (Roesch et al. 2009).

The range of the species was recorded in a survey along $2200 \mathrm{~km}$ of roads in the Brazilian Pampa sensu stricto, in regions where populations of $S$. molle are expected to be found, i.e. along disturbed environments and primary forest formations. The spatial position (altitude, longitude and latitude) for each population was recorded using a GPS device $\left(\right.$ Garmim $^{\circledR}$ e-trex). Since this species is sometimes planted by landowners in the Pampa biome, only clusters formed by at least 10 individuals with random distribution were classified as a population of $S$. molle, that originated from natural dispersion of the species (i.e. that were not planted with ornamental or economic objectives).

\section{Distribution model simulations}

To estimate the extent of occurrence and the most probable natural locations of $S$. molle occurrence in the Pampa biome we employed the maximum entropy distribution model algorithm, using the software MaxEnt version 3.3.3 (Phillips et al. 2005). This algorithm estimates the probability distribution for a species' occurrence as function of environmental limitations, based on species presence data and environmental variable layers of the study area. The model includes a deterministic outline, which enables performing confident analyses with information about presence-only point occurrences and high performance with few point localities (Phylips et al. 2005, Elith et al. 2006, Saatchi et al. 2008). The actual occurrence of S. molle within the Pampa sensu stricto was registered as latitude and longitude in the middle point of each population.

Nineteen bioclimatic variables available in the WorldClim database (http://www.worldclim.org; Hijmans et al. 2005) were extracted and used for the niche characterization in the modeling analysis. These metrics are derived from monthly temperature and rainfall values
(11 temperature and eight precipitation metrics; Table 1), representing biologically meaningful variables for characterizing species distribution (Nix 1986, Lehmann et al. 2011).

The Geographic Information System DIVAGIS (http://www.diva-gis.org) was used to compile the MaxEnt results interpolating climatic surfaces for global land areas in 2.5 arc minutes maps (about $5 \mathrm{~km}^{2}$ resolution). Model validation was determined by the area under the curve (AUC) as excellent (AUC > 0.90), good $(0.80>$ AUC $\leq 0.90)$, acceptable $(0.70$ $>$ AUC $\leq 0.80)$, bad $(0.60>$ AUC $\leq 0.70)$ and invalid $(0.50>$ AUC $\leq 0.60)$, according to Araújo et al. (2005). A Jackknife test was employed to determine the prediction power of each variable by setting the variable aside from the test and generating its percentage of contribution to the model.

\section{Results}

Excluding the crop and exotic tree species plantations and urban areas along the 2,200 km surveyed in the Brazilian Pampa sensu stricto (Figure 2B), nine populations of $S$. mole were identified. Six sites were recognized as fitting the environmental requirements for species occurrence (disturbed environments or primary forest formations), but lacked populations of $S$. mole (Figure 2B). These occurrence data and the nineteen bioclimatic variables were employed for the distribution modeling analysis, which presented an excellent predictive power (AUC $=0.99)$. The three most important bioclimatic variables, which explained more than $60 \%$ of the model, were precipitation seasonality (coefficient of variation), precipitation of the driest month and temperature seasonality (37.7\%, $13.4 \%$ and $13.3 \%$ of contribution, respectively; Table 1).

For the Pampa sensu stricto, three populations of $S$. molle (SG, VN and $\mathrm{CS}$ ) occur within the region with $100 \%$ probability of the species occurrence, five (MV, AL, SL, DP 


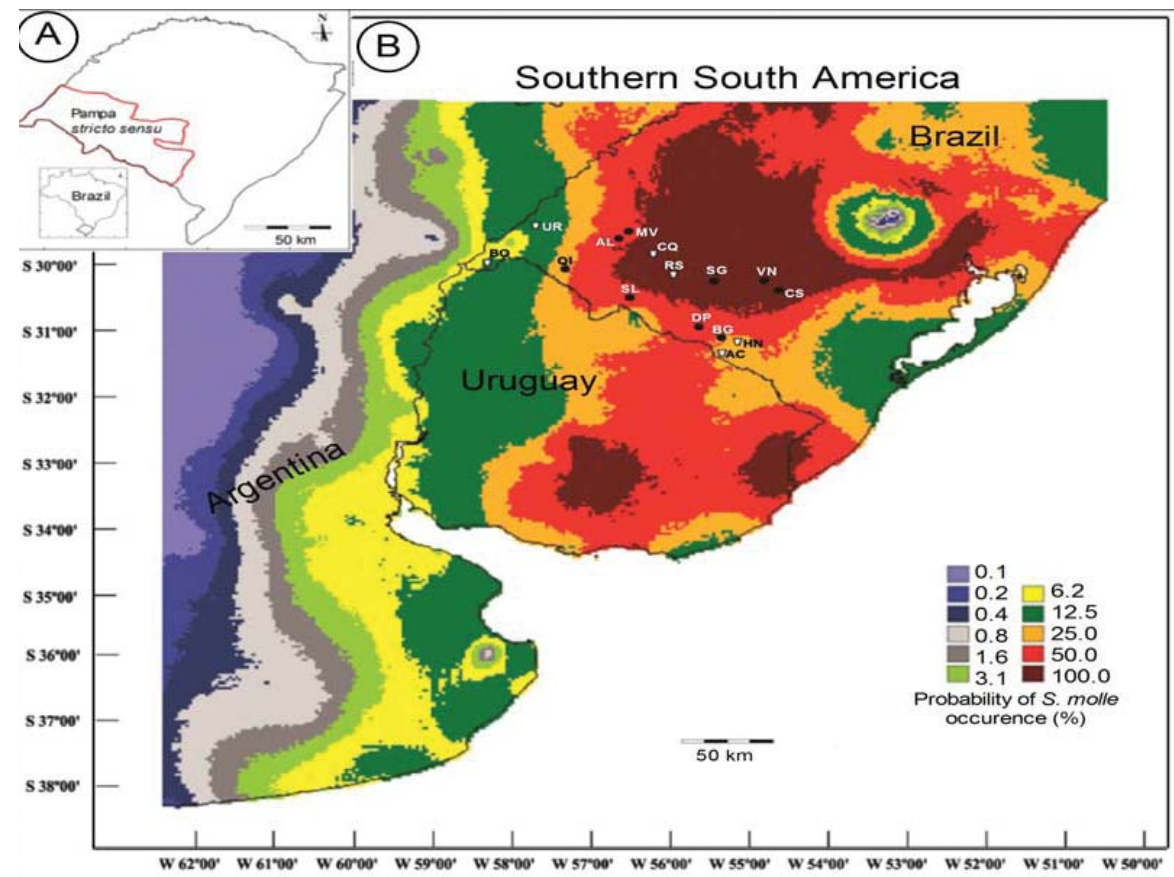

Figure 2 Map of the studied area in Southern Brazil, including the Uruguayan territory and part of Argentina. (A) Geographic range of the Pampa stricto sensu in the southernmost Brazilian state Rio Grande do Sul. (B) Predicted distribution of Schinus molle within the Pampa biome in South Brazil, Uruguay and part of Argentina. Colors represent the different probability of species occurrence based on the climatic variables evaluated. Natural populations of Schinus molle were found in Alegrete (AL), Bagé (BG), Caçapava do Sul (CS), Dom Pedrito (DP), Manoel Viana (MV), Quaraí (QI), Santana do Livramento (SL), São Gabriel (SG) and Vila Nova do Sul (VN). No populations were observed in Aceguá (AC), Cacequi (CQ), Hulha Negra (HN), Barra do Quaraí (BQ), Rosário do Sul (RS) and Uruguaiana (UR)

and $\mathrm{BG}$ ) within the region with $50 \%$ probability and one population (QI) in the region with $25 \%$ probability, near the $50 \%$ zone (Figure 2B). Among the sites where no population was found, four (BQ, UR, HN, AC) are located in regions with less than $25 \%$ predictive probability of $S$. molle occurrence. However, two sites lacking populations (CQ and RS) are located within the region of $100 \%$ probability of species occurrence (Figure 2B).

When we extrapolated the modeling to a world scale (data not shown), all regions in which $S$. molle is found as invasive/naturalized species are also characterized as propitious for species occurrence. Since our study aims to discuss forest expansion in the Brazilian Pampa, this simulation is not shown, but was used as parameter for the validation of the model, in addition to the AUC evaluation.

\section{Discussion}

Reviewing the diversity and conservation of the Pampa biome, Roesch et al. (2009) proposed that more comprehensive inventories of the biological diversity and distribution of animal and plant species and their interactions should be a key priority in future studies. Our study focused in simulating the distribution occurrence area correlated with climatic variables for a pioneer tree species. Pioneer species are important in creating suitable environments for the establishment of mid-successional tree species and the expansion of forests. We aimed to predict natural dynamics of 
Table 1 Percent contribution of the bioclimatic environmental variables used in the maximum entropy analysis for the predictive distribution of Schinus molle in the Pampa Biome

\begin{tabular}{lll}
\hline BioClim Legend & Environmental Variables & Percent contribution \\
\hline BIO 15 & Precipitation Seasonality (coefficient of variation) & 37.7 \\
BIO 14 & Precipitation of Driest Month & 13.4 \\
BIO 4 & Temperature Seasonality (standard deviation ·100) & 13.3 \\
BIO 6 & Min Temperature of Coldest Month & 7.5 \\
BIO 3 & Isothermality (BIO2/BIO7) · (100) & 6.8 \\
BIO 11 & Mean Temperature of Coldest Quarter & 6.1 \\
BIO 12 & Annual Precipitation & 5.9 \\
BIO 19 & Precipitation of Coldest Quarter & 2.9 \\
BIO 17 & Precipitation of Driest Quarter & 2.4 \\
BIO 5 & Max Temperature of Warmest Month & 1.9 \\
ALT & Altitude & 0.9 \\
BIO 8 & Mean Temperature of Wettest Quarter & 0.8 \\
BIO 1 & Annual Mean Temperature & 0.3 \\
BIO 2 & Mean Diurnal Range [Mean of monthly (max temp - min temp)] & 0.2 \\
BIO 7 & Temperature Annual Range (BIO5-BIO6) & 0 \\
BIO 9 & Mean Temperature of Driest Quarter & 0 \\
BIO 13 & Precipitation of Wettest Month & 0 \\
BIO 10 & Mean Temperature of Warmest Quarter & 0 \\
BIO 16 & Precipitation of Wettest Quarter & 0 \\
BIO 18 & Precipitation of Warmest Quarter & 0 \\
\hline
\end{tabular}

the vegetation with emphasis on the forest expansion over grasslands, as well as to propose strategies for conservation of the Brazilian Pampa. The model predicted the $S$. molle occurrence in a large area of the Brazilian Pampa sensu stricto, including all the identified populations, although with probabilities $\leq 50 \%$ for some populations. When the model was employed at a world scale (data not shown), it also included the African and North American areas where $S$. molle is found currently as an invasive/naturalized species, confirming the effectiveness of the model.

Lehmann et al. (2011) simulated the predictive occurrence area of forest and savanna environments in the Southern Hemisphere based on effective rainfall, rainfall seasonality, soil fertility and topographic complexity. Based only on these four abiotic factors and covering just from $29^{\circ} \mathrm{S}$ to $30^{\circ} \mathrm{S}$ latitude, Lehmann et al. (2011) predicted a probability $>50 \%$ of forest development in this portion of the Brazilian Pampa. Our study used a larger set of bioclimatic variables and covered a much larger portion of the Pampa biome refining these predictions and predicting the occur210 rence area of $S$. molle in the Pampa biome in a range from $0.1 \%$ to $100 \%$ probability of species occurrence. In addition, since we did not use soil fertility and topographic complexity as variables in the modeling analysis, our results suggest that these variables do not restrict the expansion of forests in the Pampa biome and that climatic variables are sufficient to predict the distribution of $S$. molle.

Precipitation seasonality (coefficient of variation), precipitation of the driest month and temperature seasonality were the three most important bioclimatic variables related to $S$. molle occurrence in our niche modeling analysis. These three bioclimatic variables are related with the presence/absence of drought periods in the environment, a factor which directly interferes with the forest establishment and expansion. Precipitation and temperature were also considered the most important climatic variables related to species richness in forest formations of southern Brazil, including the Pampean region (Oliveira-Filho et al. 2013). This is not surprising, since forest formations in the Pampa domain occur on sites where ground water accumulates (Paz \& 
Bassagoda 2002) and an increasingly warmer and moister climate is considered as the main factor enabling the forest development in this biome (Behling et al. 2005). Thus, the absence of a dry season during the year (mean of 1200 $\mathrm{mm}$ annual precipitation equally distributed over the year; Cavalcanti et al. 2009) is a crucial factor in enabling expansion of $S$. molle in the Brazilian Pampa.

The potential distribution area of $S$. molle predicted in our study with more than $50 \%$ probability covers basically all the seven different physiographic formations of the Brazilian Pampa (as well as regions outside the Pampa biome, within the Atlantic Rain Forest). Just a large extension of the coastal region and the westernmost part of the steppic-savanna environment within the Brazilian Pampa does not figure as occurrence area of $S$. molle. Based on the occurrence of economically important forest tree species, the westernmost part of the Brazilian Pampa has the lowest similarity to the other environments of the biome (Roesch et al. 2009), emphasizing the physiographic uniqueness of this region. Based on the present results, the Uruguayan Pampa revealed a smaller proportion of predicted areas with $100 \%$ probability of $S$. molle occurrence, confirming the Brazilian Pampa as a more feasible region for development of forest formations, as proposed by Rambo (1956), Hueck (1966) and Klein (1975). Although this model relies on $S$. molle only, the expansion of this pioneer species will also support the expansion of other forest species such as Luehea divaricata, Cordia trichotoma, Eugenia uniflora and Myrsine laetevirens.

The prediction of forest occurrence over much larger areas than the actual occurrence has been obtained for different regions of the world based on dynamic global vegetation models grounded on climatic and soil elements only (Bond et al. 2003, 2005). Including fire in the model, a better fit was obtained for African grassy environments, suggesting that this is an important element in shaping current forest-grassland limits and impeding forest expansion (Bond 2008). Currently, natural fire is not an element of vegetation dynamic control in the Brazilian Pampa, as indicated by the physiological dynamic of seed germination in the Pampas grassland, which are not directly stimulated to germinate by fire (Overbeck et al. 2006), and the absence of the characteristic traits of fire-resistant species in trees growing in the forest formations in this biome. Thus, expansion of $S$. molle populations over grasslands in the Brazilian Pampa seems to be the natural dynamic of this biome, extending the actual occurrence area of forests. As such demographic growth is not widely observed, we propose that ecological and anthropogenic elements are responsible by precluding the expansion of tree species populations over grasslands in the Pampa biome.

The ecological element is related to climatic variables and to the natural succession of the environment. Precipitation and temperature revealed to be the main bioclimatic factors determining the distribution area of S. molle and restricting the occurrence of the species in some regions of the Pampa biome, as shown in Figure 2B. Moreover, grasslands of the Pampa biome are resilient formations in a region where the cold and dry climate changed to warm and humid faster than the ecological dynamic of the environmental succession could evolve (Behling \& Pillar 2007). According to the palynological register (Behling et al. 2005, Behling \& Pillar 2007), the emergence of the actual wet and warm climate in southern Brazil occurred recently at both geological and ecological scales, about only 5,000 years ago. Therefore, not enough time was available for the vegetation transition from grassland to forest formations even in the areas where climatic conditions are favorable for $S$. molle establishment with more than $50 \%$ probability (Figure 2).

The anthropogenic element is linked to the historical land use in the Pampa biome. Charcoal registers from lowlands in the Brazilian 
Pampa (Behling et al. 2005) suggest that fires, probably of anthropogenic origin, were frequent in the Pampean grasslands during mid to late Holocene times. In addition, the presence of a single corn pollen grain in the pollen record suggest either a small-size corn plantation near the site or plantations distant from the site, evidencing agricultural activity at the end of this period (Behling et al. 2005). Also archeological evidences suggest that the farming Guarany folk arrived at the Uruguay River around 15,000 years ago, while domestic cattle and horses were introduced in the Jesuitical missions in the $17^{\text {th }}$ Century and spread naturally in the region after the abandonment (Schmitz 1997, Porto 1954). Currently, the expansion of agriculture and grazing lands and the establishment of exotic-tree plantations are important factors precluding the expansion of natural forests, since these activities are conducted in areas suitable for the establishment of $S$. molle and other native forest species. The absence of $S$. molle populations in regions with $100 \%$ predicted conditions for the species occurrence is likely the effect of human interference. Using mathematic models for the grassland-Araucaria forest dynamic in southern Brazil, Innes et al. (2013) proposed that human-environment interactions qualitatively alter the composition of forest-grassland mosaic ecosystems.

\section{Conclusions}

The use of "proper management strategies where grasslands are subject to shrub encroachment and forest expansion" maintaining the grassy vegetation and avoiding forest expansion has been proposed (Overbeck et al. 2007) as a policy for the conservation of the Brazilian Pampa. This proposition means the controlled use of fire and grazing in the grasslands. On the other hand, Roesch et al. (2009) suggested that the fragility of the soil, flora and fauna makes the Brazilian Pampa vulnerable to conversion and degradation, while over212 grazing and fire are the most critical threats to the biome. The present study suggests that the natural ecological dynamic of plant communities implicates the expansion of tree populations over grasslands in the majority of the Brazilian Pampa vicinity.

Thus, the forest expansion over grassland has to be considered a natural process in the biome and the conservationist actions should focus on establishing conservation unities that include forest populations and grassland, allowing the expansion of native forest species over the grassy areas. The grassland management should be used just in grazing areas with historical human interference. These actions will allow the natural succession in the Pampa biome, respecting its ecological dynamic and valuing the forest formations in this grasslanddominated environment.

\section{Acknowledgements}

We would like to thank $\mathrm{CNPq}$ (Processes 471812/2011-0 and 474758/2012-5) and UNIPAMPA (PROPESQ and PROPG) by the financial support and Leonardo Paz Deble by the fruitful discussions about the vegetation and ecological dynamics of the Pampa.

\section{References}

Araújo M.B., Pearson R.G., Thuiller W., Erhard, M., 2005. Validation of species-climate impact models under climate change. Global Change Biology 11: 1504-1513. DOI: 10.1111/j.13652486.2005.01000.x.

Asner G.P., Jones M.O., Martin R.E., Knapp D.E., Hughes R.F., 2008. Remote sensing of native and invasive species in Hawaiian forests. Remote Sensing of Environment 112: 1912-1926. DOI: 10.1016/j.rse.2007.02.043.

Behling H., Pillar V.D., 2007. Late Quaternary vegetation, biodiversity and fire dynamics on the southern Brazilian highland and their implication for conservation and management of modern Araucaria forest and grassland ecosystems. 
Philosophical Transactions of the Royal Society of London B 362: 243-251. DOI: 10.1098/ rstb.2006.1984.

Behling H., Pillar V.D., Orlóci L., Bauermann S.G., 2004. Late Quaternary Araucaria forest, grassland (Campos), fire and climate dynamics, studied by high-resolution pollen, charcoal and multivariate analysis of the Cambará do Sul core in southern Brazil. Palaeogeography, Palaeoclimatology and Palaeoecology 203: 277-297. DOI: 10.1016/ S0031-0182(03) 00687-4.

Bond W.J., 2008. What Limits Trees in C4 Grasslands and Savannas? Annual Reviews of Ecology, Evolution and Systematics 39: 641-59. DOI: 10.1146/annurev.ecolsys. 39.110707.173411.

Bond W.J., Midgley G.F., Woodward F.I., 2003. What controls South African vegetation - climate or fire? South African Journal of Botany 69: 79-91.

Bond W.J., Woodward F.I., Midgley G.F., 2005. The global distribution of ecosystems in a world without fire. New Phytologist 165: 525-538. DOI: 10.1111/j.1469-8137. 2004.01252.x.

Bredekamp G.J., Spada F., Kazmierczak E., 2002. On the origin of northern and southern hemisphere grasslands. Plant Ecology 163: 209-229. DOI: 10.1023/A:1020957807971.

Dikshit A., Naqvi A.A., Husain A., 1986. Schinus molle: a new source of natural fungitoxicant. Applied ad Environmental Microbiology 51: 10851088.

Elith J., Graham C.H., Anderson R.P., Dudík M., Ferrier S., Guisan A., et al. (2006). Novel methods improve prediction of species' distributions from occurrence data. Ecography 29: 129-151. DOI: $10.1111 /$ j.2006.0906-7590.04596.x.

Goldstein D.J., Coleman R.C., 2004. Schinus molle L. (Anacardiaceae) Chicha Production In The Central Andes. Economic Botany 58: 523529. DOI: 10.1663/0013-0001(2004)058 [0523: SMLACP]2.0.CO;2.

Hijmans R.J., Cameron S.E., Parra J.L., Jones P.G., Jarvis A., 2005. Very High Resolution Interpolated Climate Surfaces For Global Land Areas. International Journal of Climatology 25: 1965 1978. DOI: $10.1002 /$ joc. 1276.

Howard L.F., Minnich R.A., 1989. The introduction and Naturalization of Schinus molle (Pepper Tree) in Riverside, California. Landscape and Urban Planning 18: 77-95. DOI: 10.1016/01692046(89)90001-7.
IBGE, 2004. Mapa de Biomas do Brasil. [Map of the biomes of Brazil]. Rio de Janeiro, Brazil.

Innes C., Anand M., Bauch C.T., 2013. The impact of human-environment interactions on the stability of forest-grassland mosaic ecosystems. Science Report 3: 2689-2699. DOI: 10.1038/srep02689. DOI: $10.1038 /$ srep02689.

Iponga D.M., Milton S.J., Richardson D.M., 2009. Reproductive potential and seedling establishment of the invasive alien tree Schinus molle (Anacardiaceae) in South Africa. Austral Ecology 34: 678-687. DOI: 10.1111/j.14429993.2009.01975.x.

Cavalcanti I.F.A., Ferreira N.J., Dias M.A.F., Justi M.G.A., 2009. Tempo e Clima no Brasil. [Wetter and Climate in Brazil].São Paulo: Oficina de Textos.

Klein R.M., 1975. Southern Brazilian phytogeographic features and the probable influence of Upper Quaternary climate changes in the floristic distribution. Boletim Paranaense de Geociências 33: 67-88.

Lehmann C.E.R., Archibald S.A., Hoffmann W.A., Bond W.J., 2011. Deciphering the distribution of the savanna biome. New Phytologist 191: 197209. DOI: 10.1111/j.1469-8137.2011.03689.x.

Marongiu B., Porcedda A.P.S., Casu R., Pierucci P., 2004. Chemical composition of the oil and supercritical $\mathrm{CO}_{2}$ extract of Schinus molle L. Flavour and Fragrance Journal 19: 554-558. DOI: $10.1002 /$ ffj.1350.

Milton S.J., Wilson J.R.U. Richardson D.M., Seymour C.L., Dean W.R.J., Iponga D.M., Proche S., 2007. Invasive alien plants infiltrate bird-mediated shrub nucleation processes in arid savanna. Journal of Ecology 95: 648-661. DOI: 10.1111/ j.1365-2745.2007.01247.x.

Myers N., Mittermeier R.A., Mittermeier C.G., da Fonseca G.A.B., Kent J., 2000. Biodiversity hotspots for conservation priorities. Nature 403: 853-858. DOI: 10.1038/35002501.

Overbeck G.E., Muller S.C., Pillar V.D., Pfadenhauer J., 2006. No heat-stimulated germination found in herbaceous species from burned subtropical grassland. Plant Ecology 184: 237-243. DOI: $10.1007 / \mathrm{s} 11258-005-9068-1$.

Overbeck G.E., Muller S.C., Fidelis A., Pfadenhauer J., Pillar V.D., Blanco C.C., et al., 2007. Brazil's neglected biome: the South Brazilian Campos. Perspectives in Plant Ecology, Evolution and Systematics 9: 101-116. DOI: 10.1016/ 
j.ppees.2007.07.005.

Paz E.A., Bassagoda M.J., 2002. Los bosques naturales del Uruguay - Tipos y composición. [end.] Ciência e Ambiente 24:35-50. [The natural forest of Uruguay - types and composition].

Phillips S.J., Anderson R.P., Schapire R.E., 2005. Maximum entropy modeling of species geographic distributions. Ecological Modelling 190: 231259. DOI: 10.1016/j. ecolmodel.2005.03.026.

Pillar V.D., 2003. Dinâmica da expansão florestal em mosaicos de floresta e campos no sul do Brasil. In: Claudino-Sales, V. (ed.) Ecossistemas Brasileiros: Manejo e Conservação [Dynamic of the forest expansion in mosaics of forest and grasslands in South Brazil]. Fortaleza: Expressão Gráfica e Editora, pp. 209-216.

Porto A., 1954. História das Missões Orientais do Uruguai. [History of the Oriental Missions of the Uruguay] $2^{\text {nd }}$ ed. Livraria Selbach, Porto Alegre.

Rambo B., 1956. A fisionomia do Rio Grande do Sul. [The physiognomy of the Rio Grande do Sul]. Porto Alegre: Selbach, $456 \mathrm{p}$.

Roesch L.F.W., Vieira F.C.B., Pereira V.A., Schünemann A.L., Teixeira I.F., Senna A.J.T., Stefenon V.M., 2009. The Brazilian Pampa: A fragile biome. Diversity 1: 182-198.
DOI: $10.3390 / \mathrm{d} 1020182$.

Saatchi S., Buermann W., ter Steege H., Mori S., Smith T.B., 2008. Modeling distribution of Amazonian tree species and diversity using remote sensing measurements. Remote Sensing of Environment 112: 2000-2017. DOI: 10.1016/ j.rse.2008.01.008.

Schmitz P.I., 1997. Migrantes da Amazônia: a tradição Tupiguarani. In: Kern A., Jacobus A., Ribeiro P.M., Copé S., Schmitz P.I., Naue G., Becker I.B. (eds.), Arqueologia Pré-histórica do RS. [Migrants from Amazon: the Tupiguarani tradition]. $2^{\text {nd }}$ ed. Mercado Aberto, Porto Alegre, pp. 295- 330.

Sobral M., Jarenkow J.A., 2006. Flora Arbórea e Arborescente do Rio Grande do Sul, Brasil. [Arboreal and Shrub flora of the Rio Grande do Sul, Brazil]. São Carlos: RiMa, 350 p.

Vélez E., Chomenko L., Schaffer W., Madeira M., 2009. Um panorama sobre as iniciativas de conservação dos Campos Sulinos. [An overview about the conservation initiatives of the Southern grasslands]. In: Pillar V.D. et al. (eds.) Campos Sulinos: conservação e uso sustentável da biodiversidade. pp. 356-379. 